International Journal of Linguistics, Literature and Translation

ISSN: 2617-0299 (Online); ISSN: 2708-0099 (Print)

DOI: 10.32996/ijltt

Journal Homepage: www.al-kindipublisher.com/index.php/ijltt

\title{
Stylistics of The Syntactic Structures: Occurrence of the Present Tense in the Text and its time-related significance, Nizār Qabbānī's Poetic Collection Yawmiyyāt Imra'a Lā Mubāliya as a Model
}

\author{
Nassim Assadi 8 (D) \\ Assistant Professor of Arabic Language and literature, Department of Arabic Language and Literature, Sakhnin Academic College \\ for Teacher Education Sakhnin, 2173 Israel
}

Corresponding Author: Nassim Assadi, E-mail: nw626@hotmail.com

\section{ARTICLE INFORMATION}

Received: August 17, 2021

Accepted: September 18, 2021

Volume: 4

Issue: 9

DOI: $10.32996 / i j l l t .2021 .4 .9 .15$

\section{KEYWORDS}

Syntactic Structures, Phonetic Structures, Semantic Structures, Discourse Analysis, Feminine Persona, Nizār Qabbānī, Present Tense, Past Tense, Imperative verbs, Arabic Syntax

\section{ABSTRACT}

The topic of stylistics in linguistics has been of interest for linguists for many years; it's a new science that emerged in the 19th century. It is basically the scientific study of a particular style that exhibits its unique characteristics and distinctive features. The current study examines the syntactic structures and their occurrence in Nizār Qabbānī's Poetic Collection Yawmiyyāt Imra'a Lā Mubāliya. The occurrence of verbs and nouns is examined and analyzed closely and thoroughly. The time-related properties of the verbs are pointed out, and their contribution to the significance of the meaning is examined. The study aims to answer specific stylistic questions through a rigorous analysis of a selected literary work by establishing a connection between the occurrence of the verb tenses and the nouns in the collection and their relation to serving the significance and pointing out the theme of the poetic collection. Throughout the research, nouns and verbs will be identified and analyzed in each and every poem of the poetic collection. Literature review and referential language sources will be consulted to point out their characteristics and significance. The study is a combination of literary work analysis and a scientific approach to understanding the significance and the message of that work as a whole. The poetic collection, which in fact constitutes a foundation stone for the study is analyzed syntactically in terms of its structures and discourse. We observed that the ratio of verbs to nouns is (38.2\%), and we believe that the presence of verbs in this percentage is due to nature of this poetic collection which is revolutionary in most of its poems. The rejection of social norms that rendered the man an authoritarian status and the aspiration for an extensive change is expressed through the use of dynamic verbs rather than static nouns. We were also able to notice that the rise in the verbcount is directly related to how challenging it is to create change within a deeplyentrenched and old-fashioned social fabric. The study attempts to point out the connection between the syntactic structures used in the literary work and the society and time period where and when the work was generated, and to find the linguistic, philosophical and social significance of the occurrence of the present poetic collection that is used as a model.

\section{Introduction}

Stylistics of syntactic structures is an integral part of the study of style in general. Stylistics could be briefly defined as: the scientific study of a given style. A style is a linguistic structure carrying within itself a picture indicating how a writer employs speech expressions in a particular situation so that this situation reveals his literary personality, uniqueness and excellence. It is

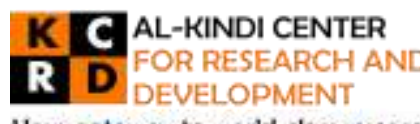

Your gateway to world-class research

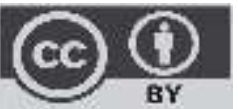

Published by Al-Kindi Center for Research and Development, London, United Kingdom. Copyright (c) the author(s). This open access article is distributed under a Creative Commons Attribution (CC-BY) 4.0 license 
about the choice of vocabulary, the composition, the degree of clarity or ambiguity, the compatibility between words and meanings, the method of imagination and photography, the formulation of phrases; their magic, the sounds and melodies, the use of rhetorical and verbal devices and the amount of innovation in all that (Al-Assadi, 2019). The style relates to the different situations, the nature of the subject, and the artistic capabilities of the writer. As for stylistics, it is a science that has its own methods through which we study the intended style and reveal its distinctive characteristics and uniqueness, and distinguish it from others. Stylistic in general examines the following:

A- The style of the phonetic structures, which in turn are divided into internal rhythmicity and external rhythmicity, each with its own branches.

B- The style of synthetic structures, which in turn are divided into grammatical structures and metaphorical structures, each with its own branches.

C- The style of semantic structures, in which semantic entities are examined in the text and the relationships between these fields are pointed out, such as tandem, contrast, partiality and inclusion (Al-Assadi, 2019).

Stylistics of syntactic structures, as mentioned above, examines the grammatical hierarchy, such as the occurrence of nouns and verbs, the use of vernacular expressions, semantics of tenses, presentation and delay, and the types of sentences in the discourse. It also examines metaphorical structures, such as; analogy, simile, and metaphor. The choice of words and the selection of structures, such as the verb phrases and noun phrases are not a standalone style unless chosen intentionally and consciously by the writer (Ben Yahia, 2011).

In this article, we will try to uncover a field of the grammatical structures, where we will address the occurrence of nouns and verbs, the connotations of tenses, its role in determining the methods of structural linguistic entities, as well as its contribution to the confirmation of significance and meaning in the text.

\section{Literature Review}

The research model is Nizār Qabbānī's Poetic Collection Yawmiyyāt Imra'a Lā Mubāliya (1968). The prior poetic collection is considered, by many scholars as a unique phenomenon in Arabic poetry; it consists of thirty-seven poems, in all of which the narrator is always a woman- from now on (feminine voice or feminine persona). Qabbani tried to convey the suffering and the pains of Oriental women to draw attention to that issue by a larger audience and more influentially. The poems of the Poetic Collection are a poetic statement of the issue of women's liberation, and they constitute a summary of a detailed stage in Qabbānī poetry in which he turned attention from women's freedom in particular to human freedom in general. If we traced the female voice in the poems of the previously mentioned poetic collection and the poet's other collections as well, we will unquestionably come to the assertive conclusion that they were all, in-depth, about women's freedom. The poems magically covey a feminine voice that not only demands freedom, but demands it with all of its shapes, forms, manifestations, and perceptions. It is indeed a wide-spectrum demand for a confiscated basic human right. A female speaker is present in every poem of the collection, perhaps a sole speaker. A declaration of massive revolution in the face of tyranny and injustices that Arab women had to endure for centuries declared. As if the poet creates a passage from a partial phase; women's freedom, to the more comprehensive one; freedom of mankind. After the 1967 war, the feminine voice calling for freedom had managed to manifest into a human voice calling for the same. Qabbānī commented on his own poetic collection by saying to all Arab women "this is your very own book, it belongs to every woman sentenced to death and demise by this idiotic, ignorant and psychopathic part of the world; the Orient" (Frangieh \& Brown, 1999). "This is where the death sentence was carried out, even before many women could even part their lips to speak." In this context, it is worth mentioning that Qabbāni was the only Arab poet who wrote an entire poetic collection throughout which only a female speaker is dominant (Al-Assadi, 2016).

For accurate results, the researcher has calculated the total number of nouns and verbs and the ratio of verbs to nouns in all of the poems. The total number of verb tenses and the ratio of each throughout the poetic collection were also calculated.

Aristotle defines two essential elements of sentences: nouns and verbs. Nouns do not require an identifying timeframe, while verbs require being identified by time (Klaus, 2014). Verbs, as defined by the philosopher, "usually refer to transient events that last only briefly, so speakers usually link them to a specific time, while nouns tend to refer to more permanent situations and therefore it is less important to determine the time when they are used (Baker, 2003). Qazwini (1993) addressed the issue of the subject in the sentence, which marks the difference between the two scholars (Ghalayini, 2014). (Al-Jarjani, 1991), and (Al-Saedi, 1991) both agree that nouns confer affirmativeness to the meaning with no implication of action repetition, continuity or renewability, whereas all the priors are conferred to a meaning when a verb is used. A noun confirms a particular meaning; it implies persistence and consistency, while a verb adds dynamicity and vividness to it. According to (Zarakshi, 2001), nouns and verbs are not meant to replace each other; a noun cannot be an alternative to a verb, and a verb cannot replace a noun in a 
sentence. Past tense is logically a reference to the past, while a present tense indicates a status quo or a future state normally. Literary works with an abundance of nouns can still be consistent and persistent as they are devoid from the element of time (Okasha, 2016). In short, a noun is more comprehensive, general, consistent, and persistent in most human languages as it cannot be time-bound, which is not applicable to verbs which are meant to speak of time and determine its frame and passage (Samirrai, 1996).

\section{Methodology}

This section of the study elaborates on what the study entails. The study is a combination of literary work analysis and a scientific approach to understanding the significance and the message of that work as a whole. The poetic collection, which in fact constitutes a foundation stone for the study is analyzed syntactically in terms of its structures and discourse.

\subsection{Research questions}

The research is an attempt to answer some fundamental questions of modern Arabic poetry in particular and modern world literature at large. The researcher takes very bold steps by questioning some firm beliefs and deep-rooted conventions of the Arab society in its depth. The research attempts to answer the following questions:

- What is the connection between the syntactic structures used in the literary work and the society and time period where and when the work was generated?

- How powerful and significant can the feminine persona in the literary work be in conveying the existential message of freedom and self-determination?

- What is the linguistic, philosophical and social significance of the occurrence of the present tense in Nizār Qabbānī's Poetic Collection Yawmiyyāt Imra'a Lā Mubāliya?

\subsection{Project design}

The aim of a project design is to ensure that the research questions are addressed effectively and logically. To develop an effective research design, the researcher adopted the following approach:

The research employs the case study approach in the collection and analysis of data. A single literary work of a preeminent Arab writer is the pillar of the study and the main source of the data available for analysis and discussion. Despite the presence of a relevant literature review within the introduction, the main source of data in the research is Nizār Qabbānī's Poetic Collection Yawmiyyāt Imra'a Lā Mubāliya.

\subsection{Participants, Materials for Research, and Study Tool}

The research investigates an issue in the society and a particular way of human behavioral code via a syntactic analysis of a literary work. The researcher investigates a phenomenon that has been a long-standing one in the Arab society, and tries to link them to revolutionary literary work through a scientific, syntactic and logical analysis of the work's content.

Discourse analysis, as a prominent academic discipline, is a fundamental tool in this study. The researcher conducts a multidisciplinary approach within the same study by carrying out a thorough socio-linguistic discourse analysis throughout the paper. A psycho-linguistic analysis of the narrator; here, the feminine persona, is also notably present as an analytical tool.

\subsection{Research Methods}

Two tables with comprehensive data appear in the study. The researcher has manually counted the occurrence of the study variables and then has conducted a statistical analysis to support his finding. The following systematic steps were undertaken:

- A literary work with unique sociolinguistic and syntactic characteristics was selected.

- Previous studies that tackle the general discipline "Syntactic Structures" were provided where supportive theoretical background was required.

- Content analysis of both the literary work and the theoretical background was conducted.

- Literary criticism, socio-linguistic analysis, psycho-linguistics analysis, discourse analysis, and data collection were all analytical tools employed in the study. 


\subsection{Study limits}

The study is limited to the stylistics of the syntactic structures; particularly the occurrence of the present tense in the Text and its time-related significance in Nizār Qabbānī's Poetic Collection Yawmiyyāt Imra'a Lā Mubāliya.

The following table addresses the distribution of nouns and verbs, and the ratio of nouns to verbs in the poetic collection Yawmiyyāt Imra'a Lā Mubāliya. It sorts the variable into verbs and nouns, providing a precise count of the occurrence of each in the poems of the poetic collection. The count is followed by an illustration of a verb-to-noun ration in each poem.

Table 1. Distribution table of nouns and verbs and the ratio of nouns to verbs in the poetic collection Yawmiyyāt Imra'a Lā Mubāliya.

\begin{tabular}{|c|c|c|c|c|}
\hline \multicolumn{2}{|l|}{ The poem } & Nouns & Verbs & Verb-to-Noun ratio \\
\hline \multirow{5}{*}{$\begin{array}{l}\text { A letter to } \\
\text { some man }\end{array}$} & 1 & 18 & 2 & $11 \%$ \\
\hline & 2 & 29 & 12 & $41 \%$ \\
\hline & 3 & 33 & 11 & $33 \%$ \\
\hline & 4 & 31 & 11 & $35 \%$ \\
\hline & 5 & 40 & 13 & $32 \%$ \\
\hline \multicolumn{2}{|l|}{1} & 57 & 24 & $42 \%$ \\
\hline \multicolumn{2}{|l|}{2} & 12 & 4 & $33 \%$ \\
\hline \multicolumn{2}{|l|}{3} & 24 & 9 & $37 \%$ \\
\hline \multicolumn{2}{|l|}{4} & 45 & 17 & $37.7 \%$ \\
\hline \multicolumn{2}{|l|}{5} & 28 & 9 & $32 \%$ \\
\hline \multicolumn{2}{|l|}{6} & 49 & 33 & $67 \%$ \\
\hline \multicolumn{2}{|l|}{7} & 48 & 19 & $39.5 \%$ \\
\hline \multicolumn{2}{|l|}{8} & 49 & 18 & $36.7 \%$ \\
\hline \multicolumn{2}{|l|}{9} & 44 & 21 & $47.7 \%$ \\
\hline \multicolumn{2}{|l|}{10} & 42 & 10 & $23.8 \%$ \\
\hline \multicolumn{2}{|l|}{11} & 59 & 8 & $13.5 \%$ \\
\hline \multicolumn{2}{|l|}{12} & 38 & 7 & $14 \%$ \\
\hline \multicolumn{2}{|l|}{13} & 17 & 10 & $58.8 \%$ \\
\hline \multicolumn{2}{|l|}{14} & 82 & 33 & $40 \%$ \\
\hline \multicolumn{2}{|l|}{15} & 32 & 1 & $3 \%$ \\
\hline \multicolumn{2}{|l|}{16} & 11 & 3 & $27 \%$ \\
\hline \multicolumn{2}{|l|}{17} & 40 & 11 & $27.5 \%$ \\
\hline \multicolumn{2}{|l|}{18} & 29 & 10 & $34.4 \%$ \\
\hline \multicolumn{2}{|l|}{19} & 20 & 11 & $55 \%$ \\
\hline \multicolumn{2}{|l|}{20} & 27 & 12 & $44.4 \%$ \\
\hline \multicolumn{2}{|l|}{21} & 48 & 17 & $35.4 \%$ \\
\hline \multicolumn{2}{|l|}{22} & 23 & 10 & $43.4 \%$ \\
\hline \multicolumn{2}{|l|}{23} & 84 & 22 & $26 \%$ \\
\hline \multicolumn{2}{|l|}{24} & 28 & 15 & $53.5 \%$ \\
\hline \multicolumn{2}{|l|}{25} & 44 & 20 & $45.4 \%$ \\
\hline \multicolumn{2}{|l|}{26} & 30 & 22 & $73 \%$ \\
\hline 27 & & 29 & 21 & $72.4 \%$ \\
\hline 28 & & 27 & 12 & $44.4 \%$ \\
\hline 29 & & 28 & 12 & $42.8 \%$ \\
\hline 30 & & 47 & 44 & $93.6 \%$ \\
\hline 31 & & 61 & 12 & $19.6 \%$ \\
\hline 32 & & 43 & 15 & $34.8 \%$ \\
\hline
\end{tabular}




\begin{tabular}{|l|l|l|l|}
\hline 33 & 32 & 16 & $50 \%$ \\
\hline 34 & 37 & 6 & $16 \%$ \\
\hline 35 & 37 & 14 & $37.8 \%$ \\
\hline 36 & 26 & 8 & $30.7 \%$ \\
\hline Total & $\mathbf{1 5 2 8}$ & $\mathbf{5 8 5}$ & $\mathbf{3 8 . 2 \%}$ \\
\hline
\end{tabular}

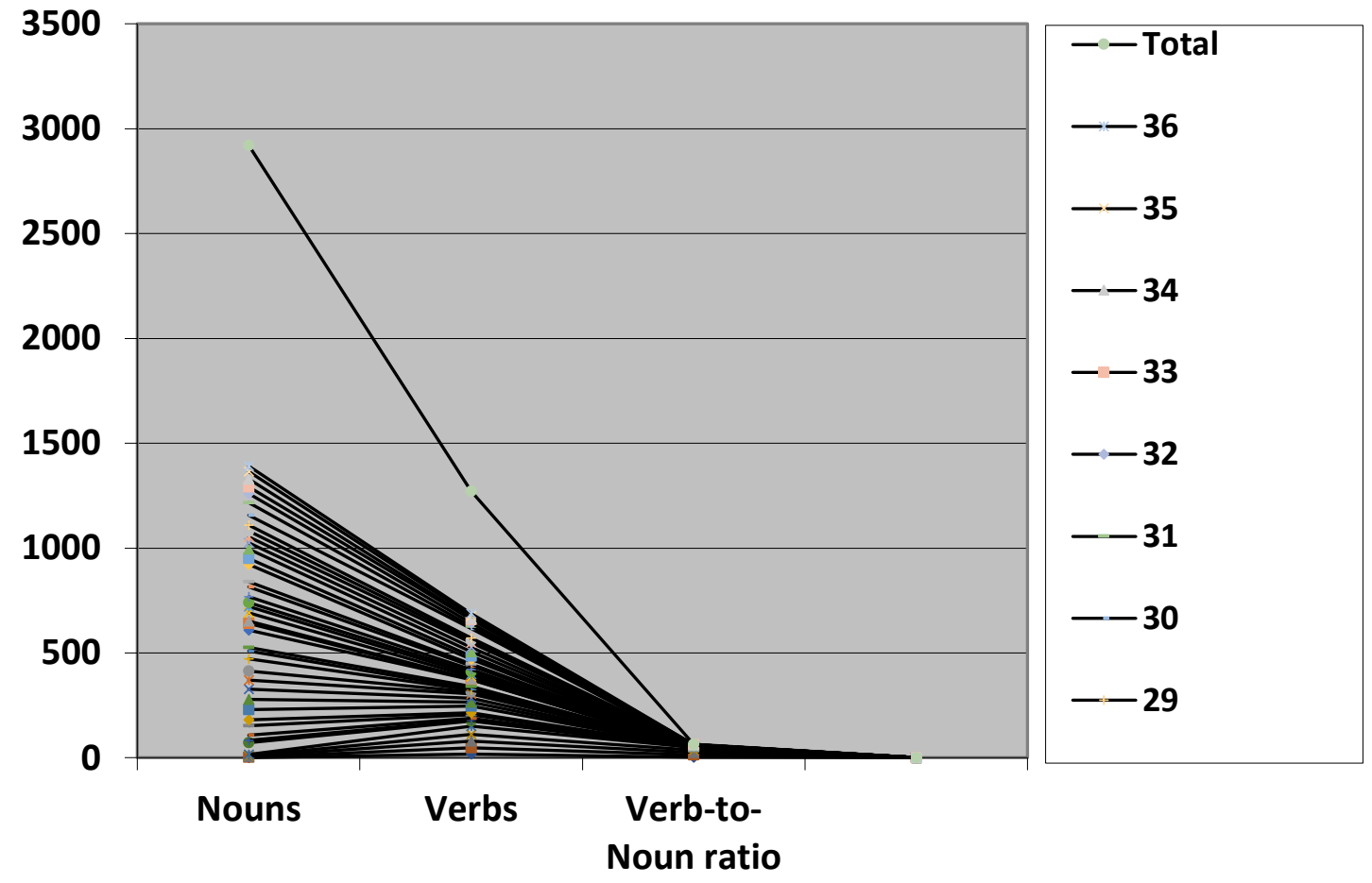

Figure 1. Distribution of nouns and verbs and the ratio of nouns to verbs in the poetic collection Yawmiyyāt Imra'a Lā Mubāliya

\section{Results and Discussion}

After sorting the verbs and the nouns in the poetic collection and determining the types of verb tenses in terms of chronological sequence, we reached the following results: the total count of verbs in the poetic collection is (585) verbs. The total count of nouns is (1528), and the ratio of verbs to nouns is (38.2\%). In some poems, this percentage falls to (13.5\%), while it notably rises in other poems to (93.6\%); as in poem No. 30. The occurrence of verbs in the poetic collection in general may be due to the presence of many poems describing the women's renewed suffering, pain and sadness. The renewal and continuity in these particular contexts may pertain to verbs rather than nouns; as verbs are linguistically in a continual state of ever-shifting, while nouns represent steadiness and persistence.

What the feminine persona goes through in poem No.30 is her longing for a man, and this longing is powerful and overwhelming as it is driven by human instinct, but, sadly, she cannot fulfill her desires and obey her instinct because her relationship with him is restricted by religion and shackled by social customs, which makes the man in this poem no more than a dream, a god, or a fearful but loved and constantly desired snake. The prior perception shows the duality experienced by the woman and the continuation of her suffering; she was raised religiously and socially that the relationship with a man outside the wedlock is forbidden, but the human instinct, on the other hand, pushes her into this relationship. This renewed struggle is presented in poem No.6, in which the ratio of verbs to nouns was relatively high at (67\%). The prior finding supports our hypothesis that the pattern of renewed suffering is in direct proportion to the presence of verbs, and that the feminine voice exists within a harsh and unyielding reality as her stunning female physique is rendered futile due to the utter absence of sexual connection with men. 
In poem 11, we find the lowest proportion of verbs-to-nouns, and it is perhaps obvious that a question should be asked about the lack of verbs here despite the renewed suffering of the female voice for its lack of freedom in love. She keeps asking the same question: why should not love to be the most natural possession for all humans without discrimination? Dissecting the poem and detecting the presence and the absence of verbs may answer our question; there are eight verbs in the poem, five of which keep appearing in the line "why would not love be?" the prior is the same sentence that keeps conveying the female's utter upset, the other sentences are in fact analogies of what love should be like, which are constants in calling upon no change or alteration, and that is why they were verb-free. An example of the prior is:

$$
\begin{aligned}
& \text { مثل أشعِّة الفجر }
\end{aligned}
$$

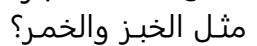

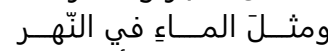

$$
\begin{aligned}
& \text { ومثلَ الغيمِ والأمطاريّ. }
\end{aligned}
$$

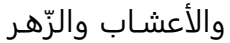

$$
\begin{aligned}
& \text { كأيّة زهـرةٍ بيضاء طالعةٍ من الصَّـر } \\
& \text { طبيعيًا } \\
& \text { كلقيا الثّغر بالثّغريعر.. } \\
& \text { ومنسابًا كما شعري على ظهري }
\end{aligned}
$$

Like the rays of dawn? like bread and wine?

Like water in a river and like clouds and rain

Like herbs and roses

Like a white flower coming out of a rock... naturally

Like the meeting of my lips and his, flowing like the strands of my hair on my back

Thus, we find a presence of verbs in sentences that describe renewed resentment, while they were not present where consistency and persistence were the dominating theme. If we look at poem No. 12, in which the feminine voice compares herself to a cat; it will eventually be associated with the freedom that the cat enjoys while she has been deprived of, we will find that the seven verbs in this poem are distributed as follows:

The present continuous verb "I am thinking is repeated twice when she compares herself to a cat:

$$
\begin{aligned}
& \text { أفكّر: أيّنَا أسعذْ أسمْ }
\end{aligned}
$$

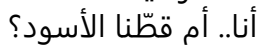

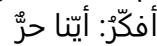

$$
\begin{aligned}
& \text { ومَن منّا طليق اليد آلنا }
\end{aligned}
$$

I'm thinking, which one is happier?

I, or our black cat?

I'm thinking, Who's free?

And not shackled?

And the verb "lives" in the poetic sentence:

$$
\text { اعيش بقمقم موصد }
$$

I live in a locked kittle

Four verbs concerning the cat that enjoying its freedom: "licks", "about to be", "worshiped" and "risen" are present in her statement:

$$
\begin{aligned}
& \text { أنا أم ذلك الحيوان } \\
& \text { يلحس فروه الأجعد؟ } \\
& \text { أمامي كائنْ حرٌّ }
\end{aligned}
$$

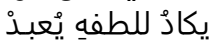

$$
\begin{aligned}
& \text { له في السّطح مملكةُ يُّة } \\
& \text { وراياتُ له تُعقد ممله } \\
& \text { I, or that animal? }
\end{aligned}
$$


The one licking its curled fur!

As I look, I only see a free creature

A creature so fine it is about to be worshiped

On the roof of that house, it has built a kingdom

And banners are held high for it

The verbs here describe two ever-renewing situations, the first being what the female voice thinks of as a result of the lack of freedom, which is a constant and renewed state, and the second describes the life of a cat full of renewed freedom and vivid activity.

In poem No. 34, we find that the proportion of verbs is low, despite the massive revolution in the poem against society. The number of verbs is only six, and their ratio to the nouns is only (16\%). How do we explain this? Another view of the distribution of these verbs in the poem shows us the positions of continuous renewal compared to all that is constant and well-established. The feminine voice revolts ferociously against the entrenched conventions of a rather static society; thus, extensive use of verbs is dominant as compared to a limited presence of nouns. An example of the prior is where the female describes herself:

$$
\begin{aligned}
& \text { أقاومٌ كلّ أسواري }
\end{aligned}
$$

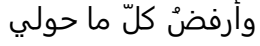

$$
\begin{aligned}
& \text { I resist all my walls } \\
& \text { And I reject everything around me } \\
& \text { أقاوم واقعي المصنوع إقاوم } \\
& \text { اقاوم كل اهل الكهف المهنوع }
\end{aligned}
$$

Nouns that infer persistence and consistency are employed to describe an old-fashioned and static society as describe here:

$$
\begin{aligned}
& \text { تواكلهم، تآكلهم، تناسلهم كأبقار } \\
& \text { أمامي ألف سيّاف تافي } \\
& \text { وخلفي ألْفُ جزّار وجزّار }
\end{aligned}
$$

Their dependence, their decay, their reproduction like cows

I have a thousand swordsmen in front of me

Behind me are a thousand butchers and thugs

\section{Verbs and their time-related implications (tenses)}

After we have tackled the presence of nouns and verbs in some poems of the Poetic collection and their relationship to the atmosphere of the poem, and the vivacity and renewal within them, we will at this part of the study, tackle the verb tenses in relation to the thematic aspects of the poems.

One of the most prominent variations between a past simple and present simple tense is the latter's capacity to convey a sense of dynamicity and movement (Ashour, 2004). A present simple tense could, in fact, contain its past counterpart and resurrect it; it could predict the future and express it exquisitely (Ashour, 2004). However, past tense is static, entrenched, and deep-rooted within a particular context and setting of time. Past tense was introduced into human languages to tell of the past. It is consistent and fixed (Dalloum, 2011). Indeed, speaking about the events of the past has a more powerful psychological effect on the listener, whereas telling of the future is nothing but a set of predictions that could prove to be wrong or misleading at any point. Al-Saedi (1991) reports that present tense is the most appropriate of all to express renewed events and states, it is a tense that was created to convey a powerful sense of continuity and dynamicity. Present tense is employed to address states of continuity and persistence, such as; monarchy, pride, riches, and authority. In Arabic literature, present tense is not used in a context of dispute or blame, as these are temporary states of affairs rather than constant and dominant ones. Present tense in Arabic enjoys a myriad of qualities such as; affirming ideas, confirming the occurrence of events, and emphasizing the presence of characters or actions. Present tense has within its structure the capacity to create a direct state of interaction with the recipient of the discourse; which attracts attention and interest. Present tense is also a powerful tool of persuasion as it only refers to live 
and tangible events and circumstances. The prior should eliminate suspicion and create a sense of trust and assurance (Al-Abd, 1999).

The following table tackles the occurrence of the three major Arabic tenses; past, present, and imperative in the poems of the poetic collection that serves as a model for the study. Each tense is counted separately and then a total count of tenses and percentage of the occurrence of each tense are provided.

Table 2. Tense occurrence in Nizār Qabbānī's Poetic Collection Yawmiyyāt Imra'a Lā Mubāliya.

\begin{tabular}{|c|c|c|c|c|}
\hline \multicolumn{2}{|l|}{ The poem } & \multirow{2}{*}{$\begin{array}{l}\text { Past tenses } \\
1 \\
\end{array}$} & \multirow{2}{*}{$\begin{array}{l}\begin{array}{l}\text { Present } \\
\text { tenses }\end{array} \\
0\end{array}$} & \multirow{2}{*}{\begin{tabular}{|l} 
Imperative tenses \\
1 \\
\end{tabular}} \\
\hline \multirow{5}{*}{$\begin{array}{l}\text { A letter to a } \\
\text { some man }\end{array}$} & 1 & & & \\
\hline & 2 & 1 & 11 & 0 \\
\hline & 3 & 4 & 7 & 0 \\
\hline & 4 & 5 & 5 & 1 \\
\hline & 5 & 4 & 8 & 1 \\
\hline \multicolumn{2}{|l|}{1} & 3 & 21 & 0 \\
\hline \multicolumn{2}{|l|}{2} & 2 & 2 & 0 \\
\hline \multicolumn{2}{|l|}{3} & 1 & 8 & 0 \\
\hline \multicolumn{2}{|l|}{4} & 0 & 17 & 0 \\
\hline \multicolumn{2}{|l|}{5} & 4 & 5 & 0 \\
\hline \multicolumn{2}{|l|}{6} & 26 & 7 & 0 \\
\hline \multicolumn{2}{|l|}{7} & 4 & 15 & 0 \\
\hline \multicolumn{2}{|l|}{8} & 1 & 17 & 0 \\
\hline \multicolumn{2}{|l|}{9} & 1 & 20 & 0 \\
\hline \multicolumn{2}{|l|}{10} & 3 & 7 & 0 \\
\hline \multicolumn{2}{|l|}{11} & 1 & 7 & 0 \\
\hline \multicolumn{2}{|l|}{12} & 0 & 7 & 0 \\
\hline \multicolumn{2}{|l|}{13} & 8 & 2 & 0 \\
\hline \multicolumn{2}{|l|}{14} & 11 & 22 & 0 \\
\hline \multicolumn{2}{|l|}{15} & 1 & 0 & 0 \\
\hline \multicolumn{2}{|l|}{16} & 0 & 3 & 0 \\
\hline \multicolumn{2}{|l|}{17} & 0 & 11 & 0 \\
\hline \multicolumn{2}{|l|}{18} & 3 & 7 & 0 \\
\hline \multicolumn{2}{|l|}{19} & 3 & 8 & 0 \\
\hline \multicolumn{2}{|l|}{20} & 2 & 10 & 0 \\
\hline 21 & & 4 & 13 & 0 \\
\hline 22 & & 3 & 7 & 0 \\
\hline 23 & & 4 & 18 & 0 \\
\hline 24 & & 6 & 9 & 0 \\
\hline 25 & & 7 & 13 & 0 \\
\hline 26 & & 3 & 19 & 0 \\
\hline 27 & & 2 & 19 & 0 \\
\hline 28 & & 1 & 11 & 0 \\
\hline 29 & & 11 & 1 & 0 \\
\hline 30 & & 4 & 40 & 0 \\
\hline 31 & & 0 & 12 & 0 \\
\hline 32 & & 2 & 13 & 0 \\
\hline 33 & & 10 & 6 & 0 \\
\hline 34 & & 2 & 4 & 0 \\
\hline 35 & & 12 & 2 & 0 \\
\hline 36 & & 6 & 2 & 0 \\
\hline Total count of te & ses & 166 & 416 & 3 \\
\hline $\begin{array}{l}\text { Percentage of } t \\
\text { tense }\end{array}$ & e occurrence of each & $2.4 \%$ & $71.1 \%$ & $0.05 \%$ \\
\hline
\end{tabular}




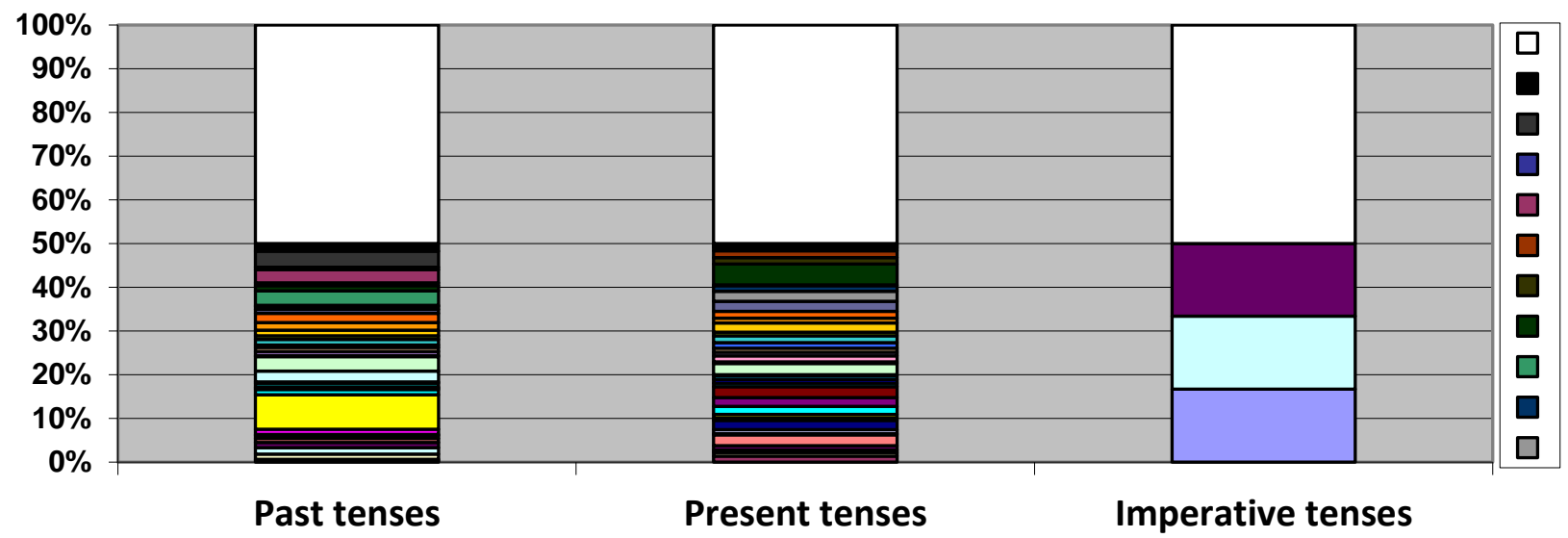

Figure 2: Tense occurrence in Nizār Qabbānī's Poetic Collection Yawmiyyāt Imra'a Lā Mubāliya.

Nizār Qabbānīs Poetic Collection Yawmiyyāt Imra'a Lā Mubāliy (Diary of an indifferent woman) is a revolutionary poetic collection by all counts. The collection does not contain a single poem where the poet flirts with a woman or describes her physically unless it is within a revolutionary context or for one. Thus, more present tenses as compared to their past counterparts should be present. The collection aims to describe the renewed reality of the Oriental woman rather than a well-established or a long-standing one. Nonetheless, in certain poems, past tenses are dominant. The prior may be due to the fact that these poems depict a constant norm and a persistent state of affairs, or the poet simply attempted to entrench these notions into the minds of the readers and confer a cognitive effect on them. Wherever present tenses were dominant, the poems depicted matters and circumstances that had continued to exist from the past throughout the present. The poet attempted to create a state of interaction between the recipient and the theme; he attempted to persuade the readers of how the matters really are. The poem "a letter to some man" is in fact constructed as a letter and is divided into three sections: introduction, body, and conclusion. In the introduction, the feminine persona introduces herself by providing consistent and unchangeable facts using only past tenses throughout. The next part of the poem has a heavy occurrence of present tenses as it only predicts the future. In the final section, present and past tenses are equal in count, still, past tenses area used to depict a possible future as they were used in conditional clauses (Chertouni, 1986), (Samirrai, 1966).

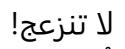

$$
\begin{aligned}
& \text { إذا كسرتُ القُمْقُمَ المسدودَ من عصور }
\end{aligned}
$$

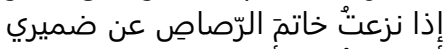

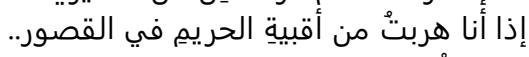

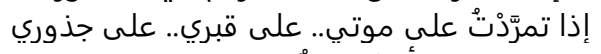

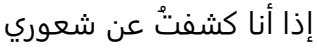

Don't be upset!

If I broke the kittle that had been locked for ages

If I took the lead ring off my conscience

If I ran away from the women's cellars in the Palaces

If I rebelled against my death, my grave, my roots

$$
\text { so, I revealed how I felt }
$$

The occurrence of the past tenses in the form of conditional clauses is also present in the third part of this poem, besides many others of the Poetic collection. It does not confer consistency or persistence; it indeed pertains to the future.

Poem No.13 had an abundance of past tenses as the poet deliberately attempted to depict the cruel past that women suffered for too long. The poet tried to create a long-lasting mental image of the events in the readers' memory. A past tense is meant to preserve the essence of the events and the characters involved in them. Due to the prior, a present tense was used in the sentences that dealt with torture and suffering. 


$$
\text { وكم اضطهدا وكم وكم ركُلدا.. }
$$

How persecuted they were and how many lashes they had endured!

For too long did they have to lie onto burning wood

Too many times they rejected their destiny

Too often had they revolted against the oppressors

Too often had they escaped their tombs

As for the questionable future, it was stated by present tenses as questions and wishes:

$$
\begin{aligned}
& \text { متى سيُفْكُّ قيـدهما؟ } \\
& \text { متسى يـا ليتنـي أدري }
\end{aligned}
$$

When will they be unchained?

What time? I wish I knew

This intensive occurrence of the past tenses is found in other poems for the same purpose. It is also notably present in the images depicting the torment of Oriental women and the extent to which they are psychologically and physically persecuted by men, or the images that represent the utmost dominance of the worn-out habits and negative ideation deeply-entrenched within the social fabric of the society, such as poems No. 6, 13, 29, 33, and 35. In poem No. 29, the feminine persona mentions the role of the clergy who exploited the woman under the pretext of being able to solve her sterility problem and help her give birth to children. It portrays a constant state of exploitation, which she wanted readers to remember. Due to the prior, the percentage of the past tense increased as opposed to past tenses (11-1). In poem No. 33, the employment of past tenses aims to address the long-standing issue of polygamy in the Arab society, an issue deeply-enriched within the fabric of the society, highly-accepted by the great majority of the its male individuals, and strongly supported by the religious narrative (Chertouni, 1986). The female persona says in this context:

$$
\text { ولم نذكر سخل بما نصنع المضجع }
$$

And we were not ashamed of our bad deeds

And we only mentioned the bed

And we took nothing with us but our four wives

Thanks to the prevalence of the past tense, the portrayal of this phenomenon is more proven and entrenched in our minds. Here, because the female persona does not offer solutions to the issue of polygamy, the percentage of verbs that are in a negative form declines to only three as compared to thirteen past tenses. The lack of solutions indicates that the situation that exists remains unchanged and constant. The prior has made the past tense dominant in the poem. In poem No. 2, which depicts the injustice of the Oriental society towards females from birth, we find that the present has been used in its negative form to address the past. The shift in the verb structure serves the purpose of creating a consistent mental image in the mind of the readers of how oppressed, and unfairly treated women are since birth, even though they are obviously with no guilt whatsoever to receive such a brutal verdict:

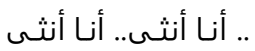

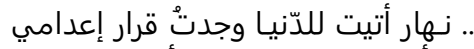

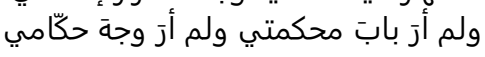


I'm a female...I'm a female

The day I came to life, I found my execution order

I didn't see the door of the court; I did not see the face of the judge either

The intensity of the present tense may be in order to convey the image of an ancient reality but, at the same time, it is there in order to exhibit the renewal of suffering and the long-lasting anguish. In poems No. 7 and 20, the female persona conveys a vivid image of her own father's oppression and tyrannical treatment of her; she uses the present tense throughout to create a sense of consistency and continuity of the patronizing treatment, torture and mistreatment that she is subjected to on a daily basis. Poem No. 26 carefully and thoroughly depicts a modern-day reality; the female persona tells the story of her elder sister who grew old without getting married. The persona talks about the massive psychological pains of her sisters and the fears that overwhelm her existence.

$$
\begin{aligned}
& \text { يروّعني } \\
& \text { شحوب شقيقتي الكبرى } \\
& \text { هي الأخرى } \\
& \text { تعاني ما أعانيه تعيش السّاعة الصّفرا } \\
& \text { تعاني عقدة سوداء تعصر قلبها عصرا عصرا }
\end{aligned}
$$

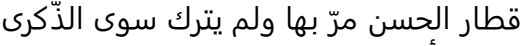

$$
\begin{aligned}
& \text { لقد بدأت سفينتها تغوصن. } \\
& \text { أراقبها وقد جلست بركن، تُصلح تُّلح الشّعرا } \\
& \text { تصفّفه.. تخرّبه وترسل زفرة زبرة حرّى تُّل } \\
& \text { تلوب.. تلوب.. في الرّدهات } \\
& \text { مثل ذبابة حيرى } \\
& \text { وتقبع في محارتها كنهر.. لم يجد مجرى }
\end{aligned}
$$

Am I petrified by how pale, how emaciated my sister is!

She has also been going through the same miseries as me

A dark complex that grinds her heart mercilessly

The train of beauty has left the station

It has left nothing but memories

Our ship is sinking, it is about to hit the rock-bottom

I am watching her, sitting in the corner, fixing her hair

And then releases another sigh

She walks in the corridors of our house, she never stops walking

Like a fly, like a river without a stream

The number of present tenses in Nizār Qabbānī's Poetic Collection Yawmiyyāt Imra'a Lā Mubāliya is (416) compared to (166) in the past. We should mention that the dominance of present tenses as opposed to their past counterparts is due to the correlation between the discourse and the time when it was generated (Okasha, 2005). Both past events and future predictions were actively employed to emphasize the present; serving a secondary function to the discourse subject itself. The overly used present tense is in fact a reference to a comprehensive revolution against an unbearable status quo.

Imperative verbs are almost absent from the poetic collection except for three places where they occur. Imperative verbs only constitute (0.05) percent of the total count of the verbs in the collection. Interestingly, all of the imperative verbs occur in one poem with which the poet starts his collection as he says:

$$
\text { اسمي أنا؟ دَعْنا منَ الأسماءٌ }
$$

"My name? How about we forget about names?

And when he says:

$$
\text { واغفرْ جُرَأتي }
$$

Forgive my courage

In the fifth part of the poem, he says:

$$
\text { قُل كلَّ ما تريدْه عيّّيِ.. فلنْ أُبالي }
$$

Say all you wish to say about me as I do not care 
The poems of Nizār Qabbānī's Poetic Collection Yawmiyyāt Imra'a Lā Mubāliya are all almost devoid of any imperative verbs. We were able to notice that imperative verbs were present in one poem; "a letter to some man' and directly after that particular poem, the collection becomes devoid of them. The prior may pertain to the fact that the poem is in fact a letter in which a man is the addressee while a woman is the speaker. In the following poems, there is no room for directly addressing men; the feminine persona writes her diary chronicling what pains her most, her fears, her daemons and her hope for a better future. Using the present tense indicate a sincere sense of optimism or at least a desperate escape from an intolerable present. A third possibility is the poets attempt to speak to the sentiments of his readers; an affective discourse, in a cognitive manner (Okasha, 2005).

\section{Conclusion}

In this article, we tackled the presence of verbs and nouns in Nizār Qabbānī's Poetic Collection Yawmiyyāt Imra'a Lā Mubāliya in terms of verb tenses as an integral part of syntactic structures, which are indeed a major constituent of the modular structures of language.

We observed that the ratio of verbs to nouns is (38.2\%), and we believe that the presence of verbs in this percentage is due to the nature of this poetic collection which is revolutionary in most of its poems. The rejection of social norms that rendered the man an authoritarian status and the aspiration for an extensive change is expressed through the use of dynamic verbs rather than static nouns. We were also able to notice that the rise in the verb-count is directly related to how challenging it is to create change within a deeply-entrenched and old-fashioned social fabric.

With regard to the significance of tenses, we found that the poems in which the past verb prevailed depict a constant state that does not change, a situation that the poet intended to carve deeply into the minds of readers in order to achieve the desired effect. The present tense was, however, prevailing in most poems that depict renewed and continuous real-time situations.

The poem "A Letter to Some Man" included all the imperative verbs in the collection. The only three imperative verbs occurred nowhere else in the collection and the reason could be related to the fact that it is the only poem where a man is an addressee, whereas the other poems are merely chronicles of a woman's constant anguish and oppression.

The very limited occurrence of future tenses in the collection could be attributed to the poet's pessimism in the future. Despite the revolutionary soul of the collection, the poet does not really believe that the future holds a better reality for Oriental women, and that the status quo, no matter how ugly and unbearable it may be, will continue to be the norm for decades to come.

Funding: The author feels obliged to point out that this research did not receive any specific grant from funding agencies in the public, commercial, or not-for-profit sectors. Author of this article is solely self-funded.

Acknowledgements: This work would not have been possible without the kind support of my colleagues, friends, and family for their kind support and encouragement. I would also like to cordially thank the translator of this original manuscript who translated the text from Arabic to English, giving it a chance to internationality. This work has not been published before in Arabic, English or any other languages, nor is it under consideration or review by any local or international journal. Author of this article declare that there is no conflict of interest whatsoever. The author also feels obliged to point out that this research did not receive any specific grant from funding agencies in the public, commercial, or not-for-profit sectors. Author of this article is solely self-funded.

Conflicts of Interest: Author of this article declare that there is no conflict of interest whatsoever.

\section{Biographical note}

Nassim Assadi is the professor of Arabic Language and Literature at Sakhnin Academic College for Teacher Education. He obtained a Bachelors' degree in Arabic and Hebrew Languages, A High Diploma of Teacher Training from the Arab College of Teacher Education, a Masters' degree in Arabic Poetry, and a Ph.D. in comparative literature, both from The University of Haifa. $\mathrm{He}$ is an avid and prominent researcher in the fields of Arabic and Hebrew languages, Comparative Literatures, Contrastive Linguistics, Phonetics and Phonology, Literary Criticism, and Methods of Teaching Arabic and Hebrew Languages. He has published numerous articles in both local and international refereed journals on various disciplines. He has also published four (4) poetic collections (Dawaween). Naseem Assadi was and still is an active participant in local and international conferences; he has also been a guest writer, editor and reviewer in several newspapers, journals and magazines worldwide. 


\section{References}

[1] Al-Assadi, N. (2019). Dialectic of style between Nizar Qabbani and Suad al-Sabah. [Doctoral Thesis]. Haifa University.

[2] Badida, R. (2011). Stylistic structures in Balqis's poem by Nizar Qabbani. [Master's thesis], Algeria: Colonel El Haj Lakhdar Batna University.

[3] Ben Yahia, M. (2011). Stylistic Features of Poetic Discourse. Irbid. The World of Modern Books.

[4] Hassan, T. (1994). Arabic Language Meanings and structure. Casablanca: House of Culture.

[5] Al-Jarjani, A. (1991). Signs of Miracles. Jeddah: Dar al-Madani. Kingdom of Saudi Arabia.

[6] Dalloum, M. (2011). Functions of Tenses in Sibaweh's. Al-Hikma Journal. Vol. 9.

[7] Zarakshi, M. (2001). The Proof in the Sciences of the Qur'an. Beirut: Dar al-Kutub,

[8] Samirrai, I. (1966). Structures of Arabic Tenses. Baghdad: Al-Ani Press.

[9] Samirrai, S. (1981). The meanings of Arabic Tenses. Kuwait: Al-Kuwait University Press.

[10] Samirrai, S. (1986). Qur'anic expression. Baghdad: Baghdad University Press.

[11] Chertouni, R. (1986). Principles of Arabic. Beirut: Dar al-Mashreq.

[12] Al-Saedi, A. (1991). High Rhetoric-Semantics. Cairi: Library of Literature.

[13] Ashour, N. (2004). Repetition in Mahmoud Darwish's poetry. Beirut: Arab Foundation for Studies and Publishing.

[14] Al-Abd, M. (1999). Researches in persuasive discourse. Damascus: Beirut: Arab Thought House.

[15] Okasha, M. (2005). The Language of Political Discourse. Cairo: University Publishing House.

[16] Ghalayini, M. (2014). The Complete Arabic Lessons. Beirut: Science Book House.

[17] Al-Qazwini,Jl. (1993). Clarification in the Science of Rhetoric. Beirut. Dar al-Jil.

[18] Qabbani, N. (2001). Diary of an indifeerent woman: Poetic collection. Kafr Qara: Dar al-Huda Printing and Publishing.

[19] Qazwini, A. (199 3). Clarification in the sciences of Rhetoric. Beirut: Dar al-Jil,

[20] Noureddine, E. (1984). Verbs and Tenses. Beirut: University Foundation for Studies, Publishing and Distribution.

[21] Frangieh, B., \& Brown, C. (1993). Nizar Kabbani's Arabian Love Poems. London: Lynne Rienner Publishers.

[22] Baker, C. (2003). Lexical categories: verbs, nouns, and adjectives. New York: Cambridge University Press.

[23] Klaus, J. (2014). Events, Arguments, and Aspects: Topics in the Semantics of Verbs. Amsterdam: Benjamins Publishing Company. 